\title{
PENINGKATAN KETERAMPILAN BERPIKIR KRITIS PESERTA DIDIK PADA PEMBELAJARAN KIMIA MENGGUNAKAN MODEL PEMBELAJARAN PREPARING DONG CONCLUDING
}

\section{IMPROVING STUDENTS' CRITICAL THINKING LEARNING IN CHEMISTRY LEARNING USING PREPARING DONG CONCLUDING LEARNING MODEL}

\author{
Zulkarnain Zulkarnain $^{1}$, Yayuk Andayani ${ }^{12 *}$, Saprizal Hadisaputra ${ }^{2}$ \\ ${ }^{1}$ Program Studi Magister Pendidikan IPA, Universitas Mataram Indonesia \\ ${ }^{2}$ Program Studi Pendidikan Kimia, Jurusan Pendidikan MIPA, FKIP Universitas Mataram Indonesia \\ *Email: yayukmtr@unram.ac.id
}

Diterima: 24 Juni 2019. Disetujui: 20 Juli 2019. Dipublikasikan: 30 Juli 2019

\begin{abstract}
Abstrak: Tujuan dari penelitian ini adalah untuk mengetahui peningkatan keterampilan berpikir kritis Peserta Didik pada pembelajaran kimia menggunakan model pembelajaran preparing dong concluding (PDC). Subjek dalam penelitian ini adalah 68 peserta didik kelas XI di SMAN 8 Mataram. Jenis penelitian ini adalah eksperimental semu. Tes yang terdiri dari 5 masalah digunakan untuk mengumpulkan data eksperimental. Indikator pemikiran kritis yang dipelajari terdiri dari 5 indikator: interpretasi, analisis, evaluasi, inferensi, dan penjelasan. Hasil penelitian menunjukkan bahwa pembelajaran dengan model PDC mampu meningkatkan keterampilan berpikir kritis peserta didik, terutama pada indikator interpretasi dengan n-gain 0,71 pada kategori tinggi. Indikator selanjutnya evaluasi masuk dan indikator analisis dengan $\mathrm{n}$-gain berturut turut 0,63 dan 0,62 dikategorikan sedang.
\end{abstract}

Kata Kunci : Model PDC, Kemampuan berpikir kritis

Abstract: This study aims to determine the increase in students' critical thinking skills in learning chemistry using the preparing dong concluding PDC learning model. The research subjects were 68 students of the eleventh grade at SMAN 8 Mataram. The research was quasi-experimental. A test consisting of 5 problems is used to collect experimental data. The studied critical thinking indicators consist of 5 indicators: interpretation, analysis, evaluation, inference, and explanation. The results showed that learning with the PDC model improved students' critical thinking skills, especially in the interpretation indicator with an n-gain of 0.71 which was categorized as a high category. The next indicators are evaluation and analysis with n-gain of 0.63 and 0.62 , respectively, categorized as medium category.

Keywords : PDC Learning Model, Critical Thinking Skill

\section{PENDAHULUAN}

Abad ke-21 dikenal sebagai abad pengetahuan yang merupakan fondasi utama bagi berbagai aspek kehidupan. Paradigma pembelajaran abad ke-21 menekankan kemampuan peserta didik untuk menjadi kreatif, berpikir kritis, mampu menghubungkan pengetahuan dengan dunia nyata, menguasai teknologi informasi, berkomunikasi, dan berkolaborasi [1]. kurikulum di abad ke-21 berfokus pada membangun pengetahuan dan mendorong peserta didik untuk mendapatkan informasi yang bermakna untuk mengembangkan keterampilan baru [2].

Berpikir kritis adalah salah satu bagian dari keterampilan belajar abad ke-21. Berpikir kritis adalah cara berpikir yang mengandung pertanyaan, percobaan, dan keyakinan terhadap pengetahuan yang telah diperoleh melalui percobaan tersebut [3]. Keterampilan berpikir kritis merupakan aspek penting dari pendidikan yang harus dikembangkan dalam menghadapi tantangan abad ke-21 [4].
Mengembangkan keterampilan berpikir kritis peserta didik dalam pembelajaran adalah upaya untuk meningkatkan hasil belajar didik [5]. Kemampuan berpikir kritis dapat dilatih dengan pembelajaran yang menuntut peserta didik untuk melakukan kegiatan percobaan, penemuan dan memecahkan masalah serta melalui diskusi dalam kelompok kecil [6].

Salah satu model pembelajaran yang inovatif dan baru adalah model pembelajaran Preparing Dong Concluding (PDC). Model pembelajaran PDC melibatkan peserta didik secara langsung dalam proses menemukan fakta dan informasi materi yang diajarkan untuk mengembangkan keterampilan berpikir kritis peserta didik [7]. Model Pembelajaran PDC dibagi menjadi 3 Tahap, yaitu; Preparing, Doing dan Concluding yang mendukung dalam pegembangan keterampilan berpikir kritis peserta didik.

Dalam penelitian ini, tahap preparing melatih keterampilan berfikir kritis dengan kegiatan 
membaca dan menulis hasil diskusi menggunakan metode resitasi dan diskusi. Metode resitasi merupakan kegiatan yang memungkinkan peserta didik untuk memperoleh pengetahuan awal yang baik [8]. Pada tahap doing digunakan metode eksperimen, diskusi dan tanya jawab. Peserta didik melakukan kegiatan mengumpulkan data, berinteraksi dan saling bertukar pendapat atau saling mempertahankan pendapat dalam pemecahan masalah. Kegiatan ini dapat melatih kemampuann berpikir tingkat kritis peserta didik [9-10]. Pada tahap concluding, peserta didik dilatih dalam keterampilan berbicara. Tahap ini juga menuntut peserta didik untuk mampu mengungkapkan pendapatnya secara bertanggung jawab, serta mampu mempertahankan pendapat yang telah disampaikannnya [11]. Hasil penelitian yang dilakukan oleh Nurhapsari [12], menunjukkan bahwa belajar menggunakan model PDC lebih efektif daripada belajar menggunakan model pembelajaran konvensional (ceramah atau hanya membaca buku paket).

Hasil observasi awal di SMAN 8 Mataram berdasarkan kuesioner yang diberikan kepada peserta didik pada tahun akademik 2018/2019 diilustrasikan dalam Tabel 1. Kuesioner berisi item yang mengarah pada visualisasi utama keterampilan berpikir kritis dan pengalaman belajar sebelumnya.

Table 1. Hasil Observasi

\begin{tabular}{|c|c|c|c|}
\hline No. & Aspek yang terkandung dalam Kuisioner & Opsi Jawaban & Persentasi Jawaban (\%) \\
\hline \multirow{2}{*}{1} & \multirow{2}{*}{ Memperoleh informasi tentang keterampilan berpikir kritis } & Pernah & 26.67 \\
\hline & & Tidak pernah & 73.33 \\
\hline \multirow{3}{*}{2} & \multirow{3}{*}{ Menerapkan indikator keterampilan berpikir kritis } & Pernah & 37.78 \\
\hline & & Sering & 4.44 \\
\hline & & Tidak pernah & 57.78 \\
\hline \multirow{3}{*}{3} & \multirow{3}{*}{$\begin{array}{l}\text { Kegiatan pembelajaran yang melatih peserta didik untuk } \\
\text { memecahkan masalah }\end{array}$} & Pernah & 35.56 \\
\hline & & Sering & 26.67 \\
\hline & & Tidak pernah & 73.33 \\
\hline
\end{tabular}

Berdasarkan data pengamatan pada Tabel 1, dapat dilihat bahwa guru tidak mengembangkan keterampilan berpikir peserta didik sesuai dengan perkembangan pembelajaran abad ke-21, yang mengharuskan peserta didik untuk memiliki keterampilan berpikir tingkat tinggi. Tujuan dari penelitian ini adalah untuk mengetahui peningkatan keterampilan berpikir kritis peserta didik yang diajarkan menggunakan model PDC.

\section{METODE PENELITIAN}

Penelitian ini menggunakan metode penelitian eksperimental. Jenis penelitian ini adalah eksperimen semu. Sampel dalam penelitian ini adalah peserta didik kelas XI di SMAN 8 Mataram sebanyak 101 peserta didik. Pengambilan sampel dilakukan dengan random sampling. Data yang diperoleh dalam penelitian ini adalah data kuantitatif. Data kuantitatif yang diperoleh dalam penelitian ini adalah data keterampilan berpikir kritis peserta didik. Data tentang keterampilan berpikir kritis peserta didik dikumpulkan melalui tes keterampilan berpikir kritis. Instrumen yang digunakan berupa deskripsi 5 pertanyaan. Data dianalisis menggunakan pre-test dan post-test one group design sederhana dengan bantuan program SPSS. Analisis data untuk menentukan efektivitas perangkat pembelajaran dilakukan dengan menggunakan uji $\mathrm{N}$-gain..

\section{HASIL DAN PEMBAHASAN}

Data uji deskriptif menunjukkan signifikansi seperti yang ditunjukkan pada Tabel 2.

Table 2. Hasil Tes Deskriptif

\begin{tabular}{llcccc}
\hline \multicolumn{5}{c}{ Paired Samples Statistics } \\
\hline \multirow{2}{*}{ Pair 1 } & Mean & N & Std. Deviation & Std. Error Mean \\
\cline { 2 - 6 } & Pre-Test & 32,08 & 68 & 7,10 & 1,22 \\
\hline
\end{tabular}

Berdasarkan Tabel 1, yang menunjukkan hasil pre-tes dan post-tes dapat ditentukan perolehan n-Gain atau peningkatan keterampilan berpikir kritis. Nilai pre-test rata-rata adalah 32.08 dan nilai posttest adalah 79.51. Dengan persamaan gain dinormalisasi Hake, nilai gain adalah 0,70 yang dikategorikan sebagai sedang. Hasil ini dapat menunjukan bahwa belajar menggunakan model PDC dapat meningkatkan keterampilan berpikir kritis peserta didik. Selanjutnya pada Gambar 1, perolehan keterampilan berpikir kritis n-Gain disajikan dalam setiap indikator keterampilan berpikir kritis. 


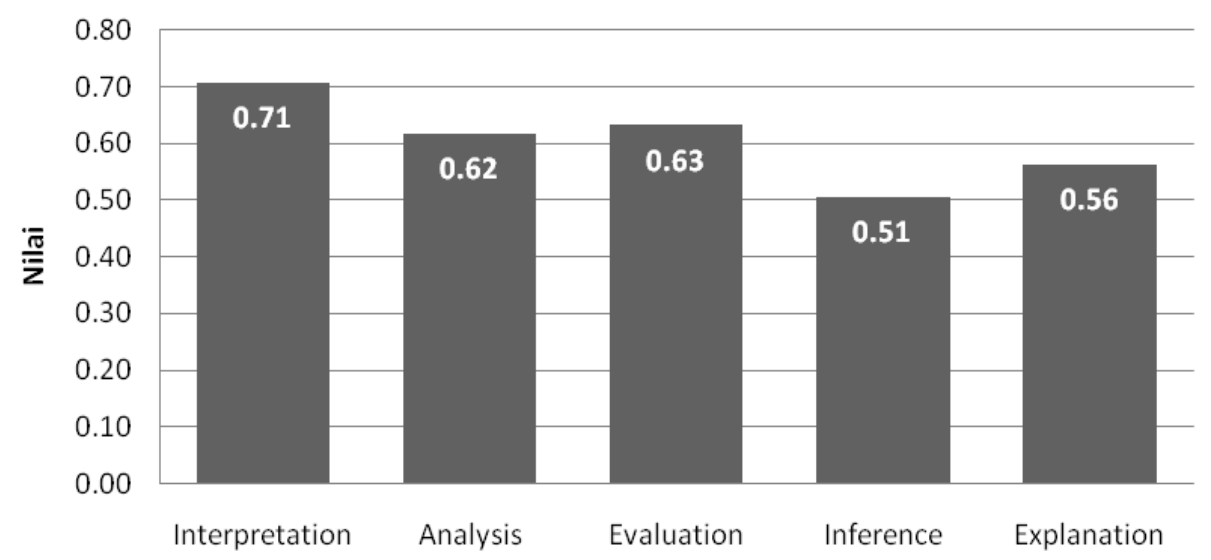

Gambar 1. Perolehan N-gain pada tiap Indikator Keterampilan Berpikir Kritis.

Gambar 1 di atas menunjukkan bahwa pembelajaran dengan model PDC mampu meningkatkan keterampilan berpikir kritis peserta didik, terutama pada indikator interpretation dengan $\mathrm{N}$-gain 0.71 dalam kategori tinggi, evaluasi dengan $\mathrm{N}$-gain 0.68 , dan analisis dengan $\mathrm{N}$-gain 0.66 . Langkah-langkah dalam model pembelajaran PDC memberikan kesempatan kepada peserta didik untuk melatih keterampilan berpikir kritis mereka. Pembelajaran dengan model PDC mampu menumbuhkan kemampuan peserta didik untuk berpikir dan bekerja secara ilmiah.

Model Pembelajaran PDC adalah model pembelajaran yang dibagi ke dalam tiga fase, yaitu: Preparing, Doing dan Concluding. Pembelajaran dengan model PDC dipandu melalui penerapan tujuh tahap pembelajaran yaitu: pada fase Preparing meliputi: (1) Kegiatan resitasi, (2) Diskusi kelompok tentang materi yang telah dibaca dengan membuat pertanyaan, dan (3) Menulis resume dari hasil pengamatan dan bacaan terkait materi. Adapun tahap-tahap Doing meliputi: (4) Diskusi kelompok mengumpulkan informasi, melaksanakan percobaan, menganalisis, dan pemecahan masalahnya, (5) Diskusi kelompok untuk mencocokkan hasil percobaan dengan teori, dan (6) Membuat laporan hasil percobaan. Kemudian tahap pada fase Concluding adalah (7) Mempresentasikan hasil percobaan dan membuat kesimpulan [13].

Gambar 1 menunjukan bahwa indikator interpretation memiliki peningkatan tertinggi di antara empat indikator lainya. Hal ini disebabkan karenan peseta didik telah memiliki pengetahuan awal yang kuat melalui kegiatan resitasi pada fase preparing. Peserta didik yang memiliki pengetahuan awal yang kuat maka akan lebih mudah menguasai konsep yang baru [14]-[15]. Kemudian melalui kegiatan diskusi kelompok pada fase ini peserta didik di latih untuk mampu mengungkapkan makna dari fenomena-fenomena ilmiah yang di sajikan dalam materi bacaan. Diskusi kelompok merupakan suatu kegiatan dimana peseta didik saling berbagi ide dan pendapat mereka untuk mendapatkan konsep yang benar dari data-data yang mereka kumpulkan [16] Indikator evaluasi juga menunjukan peningkatan yang tinggi berdasarkan Gambar 1. Hal ini di sebabkan karena dalam fase concluding, peserta didik dilatih untuk mampu memberikan tanggapan dan kesimpulan. Hal ini didapatkan melalui kegiatan presentasi hasil percobaan oleh setiap kelompok pada fase concluding. Melalui hasil pengamatan oleh peserta didik, guru dapat melihat keberhasilan peserta didik mencapai tujuan pembelajaran [17].

Selanjutnya indikator analisis juga menunjukan peningkatan dengan perolehan n-Gain yang tinggi. Hal ini disebabkan karena dalam fase doing, peserta didik melakukan percobaan, mengamati proses serta menuliskan hasil percobaan untuk mengembangkan keterampilan berpikir kritis peserta didik. Pembelajaran dalam kegiatan percobaan telah dilaporkan oleh banyak peneliti [18]-[20]. Dengan demikian bahwa, pada fase ini peserta didik dilatih dalam melakukan analisis dan pemecahan masalah yang berkorelasi dengan peningkatan kemampuan berpikir kritis.

Dampak yang menyertai dari model pembelajaran PDC adalah munculnya keterampilan berpikir kritis. Hal ini dapat dilihat dari peningkatan skor n-Gain pada tiap indikator keterampilan berpikir kritis. Peningkatan ini disebabkan oleh pembelajaran yang mengasah kemampuan berpikir kritis peserta didik. Berpikir kritis dapat ditingkatkan melalui aktivitas mengembangkan pengetahuan dan konten keterampilan proses dan pembentukan mental secara bersamaan[21].

\section{KESIMPULAN}

Berdasarkan hasil penelitian dapat disimpulkan bahwa pembelajaran dengan model PDC mampu meningkatkan keterampilan berpikir kritis peserta didik, terutama pada indikator 
penjelasan dengan $\mathrm{N}$-gain 0.72 dalam kategori tinggi, evaluasi dengan $\mathrm{N}$-gain 0.68 , dan analisis dengan $\mathrm{N}$ gain 0.66 .

\section{DAFTAR PUSTAKA}

1. Ismail, S. N., Don, Y., Husin, F., \& Khalid R. (2018). Instructional Leadership and Teachers' Functional Competency across the 21st Century Learning. International Journal of Instruction, 11(3), 135-152.

2. Alismail, H. A., \& McGuire, P. (2015). 21st Century Standards and Curriculum: Current Research and Practice. Journal of Education and Practice, 6(6), 150-154.

3. Munandar, H., Sutrio, S., \& Taufik, M. (2018). Pengaruh Model Pembelajaran Berbasis Masalah Berbantuan Media Animasi Terhadap Kemampuan Berpikir Kritis dan Hasil Belajar Fisika Siswa SMAN 5 Mataram Tahun Ajaran 2016/2017. Jurnal Pendidikan Fisika dan Teknologi, 4(1), 111-120.

4. Hadi, S. A., Susantini, E., \& Agustini, R. (2018, January). Training of students' critical thinking skills through the implementation of a modified free inquiry model. In Journal of Physics: Conference Series (Vol. 947, No. 1, p. 012063). IOP Publishing.

5. Corebima, H. S. A. D. (2017). Empowering critical thinking skills of the students having different academic ability in biology learning of Senior High School through PQ4R-TPS Strategy. The International Journal of Social Sciences and Humanities Invention, 4(5), 35213526.

6. Aini, Z., Ramdani, A., \& Raksun, A. (2018). Perbedaan Penguasaan Konsep Biologi Dan Kemampuan Berpikir Kritis Siswa Kelas X Pada Penerapan Model Pembelajaran Kooperatif Tipe Group Investigation Dan Guided Inquiry di MAN 1 Praya. Jurnal Pijar Mipa, 13(1), 19-23.

7. Nurhapsari, R. (2016). Karakteristik Pengembangan Model Pembelajaran PDC (Preparation, Doing, Conclussion) untuk Pembelajaran IPA di SMP. Jurnal Pembelajaran Fisika, 4(5), 250-261.

8. Aditya, D. Y. (2016). Pengaruh Penerapan Metode Pembelajaran Resitasi terhadap Hasil Belajar Matematika Siswa. SAP (Susunan Artikel Pendidikan), 1(2).

9. Susilawati, S., Jamaluddin, J., \& Bachtiar, I. (2017). Pengaruh Model Pembelajaran Berbasis Masalah (Pbm) Berbantuan Multimedia Terhadap Kemampuan Berpikir Kritis Peserta Didik Kelas Vii SMP Negeri 2 Mataram Ditinjau Dari Kemampuan Akademik. Jurnal Pijar Mipa, 12(2), 64-70.

10. Gayatri, I. G. A. S., Jekti, D. S. D., \& Jufri, A. W. (2013). Efektifitas pembelajaran berbasis masalah (PBM) dan strategi kooperatif terhadap kemampuan menyelesaikan masalah dan hasil belajar kognitif biologi ditinjau dari kemampuan akademik awal siswa kelas X SMA Negeri 3 Mataram. Jurnal Pijar Mipa, 8(2).

11. Weda, D. (2014). Pengaruh Model Pembelajaran Role Playing terhadap Keterampilan Berbicara Bahasa Indonesia Siswa Kelas V. Jurnal MIMBAR PGSD. Vol. 2 (1): 1-10.

12. Nurhapsari, R. (2017). The Retention of Learning Achievement in Natural Science with PDC Instructional Model (Preparing, Doing, Concluding) in Grade 8-th at Junior High School 02 of Umbulsari. Pancaran Pendidikan, 6(3).

13. Nurhapsari, R., Sutarto, S., \& Mahardika, I. K. (2016). Pengembangan Model Pembelajaran PDC (Preparing, Doing, Concluding) untuk Pembelajaran IPA. Jurnal Pembelajaran dan Pendidikan Sains, 1(1), 9-16.

14. Maesyarah, M., Jufri, A. W., \& Kusmiyati, K. (2015). Analisis Penguasaan Konsep Dan Miskonsepsi Biologi Dengan Teknik Modifikasi Certainty Of Response Index Pada Siswa Smp Se-Kota Sumbawa Besar. Jurnal Pijar Mipa, 10(1).

15. Ramandha, M. E. P., Andayani, Y., \& Hadisaputra, S. (2018, October). An analysis of critical thinking skills among students studying chemistry using guided inquiry models. In AIP Conference Proceedings (Vol. 2021, No. 1, p. 080007). AIP Publishing.

16. Rahmayanti, N., Muntari, M., \& Siahaan, J. (2014). Pengaruh Penerapan Model Pembelajaran Diskusi Kelas dengan Teknik Buzz Group Terhadap Prestasi Belajar Siswa Kimia Materi Pokok Hidrokarbon. Jurnal Pijar MIPA, 9(1).

17. Mitasari, Z., \& Prasetiyo, N. A. (2016). Penerapan metode diskusi-presentasi dipadu analisis kritis artikel melalui lesson study untuk meningkatkan pemahaman konsep, kemampuan berpikir kritis, dan komunikasi. Jurnal Bioedukatika, 4(1), 11-14.

18. Marheni, N. P., \& Suardana, I. N. (2017). Pembelajaran Inkuiri Terbimbing Berbasis Budaya Lokal pada Pembelajaran Sains Kimia SMP. Wahana Matematika dan Sains: Jurnal Matematika, Sains, dan Pembelajarannya, 8(2), 87-100.

19. Emda, A. (2017). Laboratorium Sebagai Sarana Pembelajaran Kimia dalam Meningkatkan Pengetahuan dan Ketrampilan Kerja Ilmiah. Lantanida journal, 5(1), 83-92.

20. Yuliani, K., \& Saragih, S. (2015). The Development of Learning Devices Based Guided Discovery Model to Improve Understanding Concept and Critical Thinking 
Mathematically Ability of Students at Islamic Junior High School of Medan. Journal of education and practice, 6(24), 116-128.

21. Irwanto, A. D. Saputro, E. Rohaeti, and A. K. Prodjosantoso, Promoting Critical Thinking and Problem Solving Skills of Preservice
Elementary Teachers through Process-Oriented

Guided-Inquiry Learning (POGIL). International Journal of Instruction, 11(4), 777794, 2018. 